\title{
Neutrophil-to-Lymphocyte Ratio for the Assessment of Long-term Mortality in Patients with Heart Failure
}

\section{Kalp Yetersizliği Hastalarında Nötrofil-lenfosit Oranının Uzun Dönem Mortalite ile İlişkisi}

• Ümran Keskin ${ }^{1}$, • Nuran Günay ${ }^{2}$, Kadir Kayataş ${ }^{1}$

${ }^{1}$ University of Health Sciences Turkey, Haydarpaşa Numune Training and Research Hospital, Clinic of Internal Medicine, Istanbul, Turkey

${ }^{2}$ University of Health Sciences Turkey, Ümraniye Training and Research Hospital, Clinic of Cardiology, İstanbul, Turkey

Background: The neutrophil-to-lymphocyte ratio (NLR) is a novel inflammatory parameter, which has a predictor value in different cardiovascular disorders. The objective of this study is to evaluate the predictive value of the NLR for long-term mortality (5-year) in patients with heart failure.

Materials and Methods: We retrospectively investigated the association between NLR and mortality in 785 patients who presented with CHF between 2006 and 2010. Of these, 201 patients were excluded because of factors that could impact the NLR level. Five hundred eighty four patients were categorized by the respect of low (NLR $<1.5)$, intermediate $(1.5 \leqslant N L R<3)$, and high $(N L R \geqslant 3)$ tertiles of NLR and were followed for 5 years. Cox-proportional regression analysis was used to establish the relationship between NLR levels and all-cause long-term mortality.

Results: The mean NLR was $2.82 \pm 2.54$. The lowest long-term mortality was determined in patients with NLR level of $<1.5$. In a multivariable Cox-proportional regression analysis, the mortality risk was higher for patients with NLR of $\geqslant 1.5$ [hazard ratio (HR), 1.98, 95\% confidence interval ( $\mathrm{Cl}) 0.98-3.42$ and $\mathrm{HR}, 4.22,95 \% \mathrm{Cl} 2.66-5.86$, for patients with $1.5 \leqslant \mathrm{NLR}<3$ and NLR $\geqslant 3$, respectively]. Additionally, NLR showed a significant correlation with B-type natriuretic peptide (BNP). The Spearman correlation coefficient identified the significant threshold effect (coefficient $=0.34, p<0.001$ ).

Conclusion: We detected a significant association between the NLR and long-term mortality. Additionall, NLR showed a significant correlation with BNP. Therefore, NLR may become a simple and cheap biomarker in the state of unavailability of BNP.

Keywords: Neutrophil-to-lymphocyte ratio, heart failure, mortality

Amaç: Nötrofil-lenfosit oranı (NLO) yeni bir enflamatuvar parametre olup farklı kardiyovasküler alanlarda prediktif öneme sahiptir. Bu çalışmanın amacı NLO’nun kalp yetersizliği hastalarının 5-yıllık sağkalımındaki rolünü araştırmaktır.

Gereç ve Yöntemler: Bu retrospektif çalışmada 2006-2010 yılları arasında hastanemizde yatan 785 kalp yetersizliği hastası araştırılmıştır. NLO seviyesini etkileyebilecek durumu olan 201 hasta çalışmadan çıkarıldı ve kalan 584 hasta NLO seviyesine göre 3 gruba ayrıldı; düşük (NLO <1,5), orta $(1,5 \leqslant N L R<3)$ ve yüksek (NLR $\geqslant 3)$ ve bu hastaların 5 yıllık sağkalımları kayıt edildi. NLO’nun uzun dönemdeki bağımsız ilişkisini araştırmak için Cox-regresyon analizi kullanıldı.

: Bulgular: Ortalama NLO değeri 2,82 $\quad$ 2,54 olarak bulundu. En düşük mortalite NLO $<1,5$ olan hastalarda izlendi. Çoklu değişkenli Cox-regresyon analizinde mortalite riski NLO $\geqslant 1,5$ olan hastalarda daha fazla bulundu [sırasıyla $1,5 \leqslant$ NLO $<3$ ve NLO $\geqslant 3$ olanlar için risk oranı (RO), 1,98, \%95 güven aralığı (GA) 0,98-3,42 ve RO, 4,22, \%95 GA 2,66-5,86]. Ayrıca NLO ile BNP arasında ciddi bir korelasyon saptandı (Spearman korelasyon katsayısı: 0,34, $p<0,001$ ).

Sonuç: Çalışmamızda NLO ile uzun dönem mortalite arasında bağımsız bir ilişki saptandı. Ayrıca NLO ile BNP arasında ciddi bir korelasyon izlendi. BNP'ye ulaşılamadığı durumlarda NLO ucuz ve basit bir biyobelirteç olarak kullanılabilir.

Anahtar Kelimeler: Nötrofil-lenfosit oranı, kalp yetersizliği, mortalite

Address for Correspondence: Ümran Keskin, University of Health Sciences Turkey, Haydarpaşa Numune Training and Research Hospital, Clinic of Internal Medicine,

İstanbul, Turkey

Phone: +90 5535451454 E-mail: drumrankeskin@gmail.com ORCID ID: orcid.org/0000-0002-7494-2733

Received: 26.07.2020 Accepted: 30.09 .2020 


\section{Introduction}

Despite the fact that in medical and device-dependent treatments, physicians from all departments still encounter congestive heart failure (CHF) frequently in the clinical practice as a common health and heart problem with high morbidity and mortality. There are current studies showing that inflammation has a substantial predictive role in the initiation and progression of cardiovascular diseases $(1,2)$. Brain-type natriuretic peptide (BNP) is commonly suggested as an exclusion criterion in CHF. Furthermore, BNP is a great prognostic value in patients with CHF (3). However, BNP is relatively expensive and is not available in all health centers. Complete blood count test is a cheap and widespread test which is in use. Usage of hematological parameters as an prognostic and predictive marker in cardiovascular diseases has been intensively investigated in recent years $(4,5,6)$. Among the different hematological parameters, neutrophil-to-lymphocyte (NLR) has become prominent as a marker of underlying inflammation. The aim of the current study is to evaluate the predictive value of NLR in long-term mortality. Additionally, we have hypothesized that NLR may become a diagnostic parameter in case of unavailability of BNP.

\section{Material and Methods}

Between January 2006 and December 2010, 786 consecutive patients diagnosed with CHF, who were admitted to our hospital, were evaluated retrospectively for the current study. CHF is defined as a syndrome in which patients have typical symptoms (e.g. breathlessness, ankle swelling, and fatigue) and signs (e.g. elevated jugular venous pressure, pulmonary crackles, and displaced apex beat) resulting from an abnormality of cardiac structure or function (3). The current study was based on the patients with chronic CHF. A total of 201 patients who had an affecting factor that could change the NLR levels, including systemic disease and use of medical treatment with chemotherapy, having evidence of any concomitant inflammatory disorder, acute and chronic infection, receiving the glucocorticoid therapy within the past 3 months, having Acute Coronary syndrome and percutaneous coronary intervention in the past 6 months, having secondary hypertension and acute decompensated CHF, were excluded. This study was approved by the institutional ethical and scientific committee.

\section{Data Sources}

Clinical, demographic, historical, angiographic, treatment and laboratory data were obtained from the hospital's medical database. Complete blood counts, which included total white blood cell, neutrophils, lymphocytes, monocytes, and eosinophils, were obtained at the time of admission. All patients were evaluated for the presence of cardiovascular risk factors such as hypertension, hyperlipidemia, diabetes mellitus, and smoking status. Echocardiogram was performed by trained cardiologists and left ventricular ejection fraction (LVEF) was calculated by using the Simpson method (7). Left ventricular dilatation is defined as a left ventricular diastolic diameter of $>60 \mathrm{~mm}$. The estimated glomerular filtration rate (eGFR) was calculated by using the Cockcroft-Gault equation (8). The drugs were administered during the hospitalization according to the European Society of Cardiology Guidelines (3). NLR was calculated as the ratio of neutrophil count to lymphocyte count. NLR levels for each patient were collected and reviewed by a trained coordinator. Patients were classified into 3 groups to evaluate the association between the long-term mortality and NLR levels: $\leqslant 1.5,1.5$ to 3.0 , and $\geqslant 3.0$. The aim of this study was to evaluate the prognostic impact of the NLR on long-term mortality in patients with CHF. The evaluation of mortality was obtained from hospital's medical database or by follow-up interviews (directly or by telephone). The primary end point was long-term (5-year) mortality

\section{Statistical Analysis}

Baseline characteristics were compared among the patients by NLR level and categorized accordingly as $\leqslant 1.5,1.5$ to $<3.0$, and 23.0. The Kolmogorov-Smirnov test was used for evaluating normality. Continuous variables with normal distributions were expressed as mean \pm standard deviation and compared using One-Way analysis of variance. Continuous variables with skewed distributions were expressed as median $\left(25^{\text {th }}\right.$ and $75^{\text {th }}$ percentiles) and compared using the Kruskal-Wallis test. Categorical variables were expressed as number and percentages and the Pearson's chi-square or Fisher's Exact tests were used to evaluate the differences. Correlation analyses between the NLR and BNP were made using the Spearman test. The receiver operating characteristic (ROC) analysis was used to assess the ability of the NLR and BNP to predict the mortality. After follow-up periods of $24.32 \pm 15.81$ months, the median survival time of three groups was compared using the KaplanMeier survival method. Overall survival (OS) was calculated from the day of diagnosis to the day of death or last followup. Patients lost to follow-up were censored at the time of last follow-up. Differences between the groups were analyzed by the log-rank test. A forward Cox-proportional regression model was used for multivariable analysis. The hazard ratios indicate the relative risk of death in NLR level subgroup compared to those in the lowest-risk subgroup (NLR <1.5). In multivariable models, confounders in bivariate analysis as predictors of longterm mortality were considered. Five different models were generated to obtain the impact of potential confounders on the association between NLR level and mortality. These 5 models include: (1) unadjusted; (2) adjusted for age, sex; (3) adjusted 
for comorbidities and eGFR; (3) adjusted for treatments; (5) adjusted for all confounders including demographics (age, gender), first measurement of the following laboratory values (creatinine, brain type natriuretic peptide, admission glomerular filtration rate calculated by Cockcroft Gault, glucose, sodium, potassium, C-reactive protein, total protein, albumin, aspartate aminotransferase, alanine aminotransferase, gama-glutamyl transferase, total bilirubin, white blood cell count, neutrophil count, lymphocyte count, monocyte count, eosinophil count, hematocrit, red cell distribution width, platelet count, mean platelet volume, plateletcrit), comorbidities (diabetes, hypertension, hyperlipidemia, cerebrovascular disease, chronic obstructive pulmonary disease, atrial fibrillation, left ventricular dilatation), and treatments. Acute kidney injury is defined as an increase in serum creatinine level of $\geqslant 0.3 \mathrm{mg} / \mathrm{dL}$ or a relative increase in serum creatinine level of $\geqslant 50 \%(9,10)$. A two-tailed p-value of $<0.05$ was considered as statistically significant, and $95 \% \mathrm{Cls}$ were presented for hazard ratios. Analyses were performed using the Statistical Package for Social Sciences software, version 20.0 (SPSS; IBM, Armonk, New York, USA).

\section{Results}

A total of 584 patients (mean age $42.6 \pm 10.9$ years; men $81 \%$ ) with CHF were included. There was a significant difference in terms of gender age $(p<0.001)$ among the subgroups of NLR whereas there was no significant difference in terms of gender $(p=0.076)$. The patients' baseline characteristics, categorized by NLR level, are listed in Table 1. Overall, NLR was significantly correlated directly with BNP $(r=0.34, p<0.001)$. The groups were similar in terms of history of hypertension, diabetes mellitus, current smoking status, ischemic heart failure, percutaneous coronary intervention, coronary artery bypass graft surgery, and atrial fibrillation. Hyperlipidemia was more common in patients with NLR of $<1.5$, whereas chronic kidney disease was more common in patient with $N L R$ of $\geqslant 3$. At admission, there were significant differences in terms of systolic blood pressure (0.012) and diastolic blood pressure (0.008). The New York Heart Association status was higher and LVEF was lower in patients with INR level of $\geqslant 3$. In admission laboratory variables; BNP, blood fasting glucose, creatine, C-reactive protein, aspartate aminotransferase, alanine aminotransferase, gama glutamyl transferase and total bilirubin were higher in patients with serum NLR level of $\geqslant 3$. Among the hematological parameters; white blood cell count, netrophil count, monocyte count, eosinophil count and red cell distribution width were higher in patients with serum NLR level of $\geqslant 3$. In treatments; inverter cardioverter defibrillator or cardiac resynchronization therapy, digoxine, mineralocorticoid receptor antagonist and furosemide were more commonly used in patients with NLR level of $\geqslant$
3. A correlation analysis performed using a Spearman test revealed that there was a correlation between the NLR and the BNP in the study population ( $r=0.340, p<0.001)$ (Figure 1). After ROC analysis, the best cut-off value of the BNP to predict the mortality was $445 \mathrm{pg} / \mathrm{mL}$ with $71 \%$ sensitivity and $80 \%$ specificity [area under the curve (AUC): 0.83 ; $95 \% \mathrm{Cl}: 0.78-$ $0.87, p<0.001$ ], and the best cut-off value of the NLR to predict the mortality was 2.3 with $71 \%$ sensitivity and $63 \%$ specificity (AUC: 0.74, 95\% Cl: 0.68-0.78, p<0.001) (Figure 2).

The patients were followed up for a mean period of $24.32 \pm 15.81$ months. The 5-year Kaplan-Meier OS for NLR level of <1.5, 1.5 to 3.0 and $>3.0$ were $91.2 \%, 77.6 \%$ and $53.7 \%$, respectively. The Kaplan-Meier cumulative survival curve was shown in Figure 3. Table 2 lists unadjusted and adjusted Cox-proportional regression analysis for long-mortality categorized by NLR levels. The long-term mortality had the highest rates at NLR level of $>3$ and those were 4.5-times higher mortality rates (95\% Cl: $2.35-8.78)$ than NLR level of $<1.5$, which had the lowest rates and which was used as the reference. This relationship persisted even after the adjustment for all confounders. Patients with NLR level of 1.5 to 3 was also had 2-times higher mortality rates ( $95 \% \mathrm{Cl}: 0.97-3.67)$ than the reference group.

\section{Discussion}

Inflammatory response has commonly been considered in both the progression and clinical worsening of HF. In the current study, we evaluated the leukocytic response in heart failure and its possible relationship with long-term mortality. The main findings of the current study were that a high NLR at hospital admission was associated with increased long-term mortality

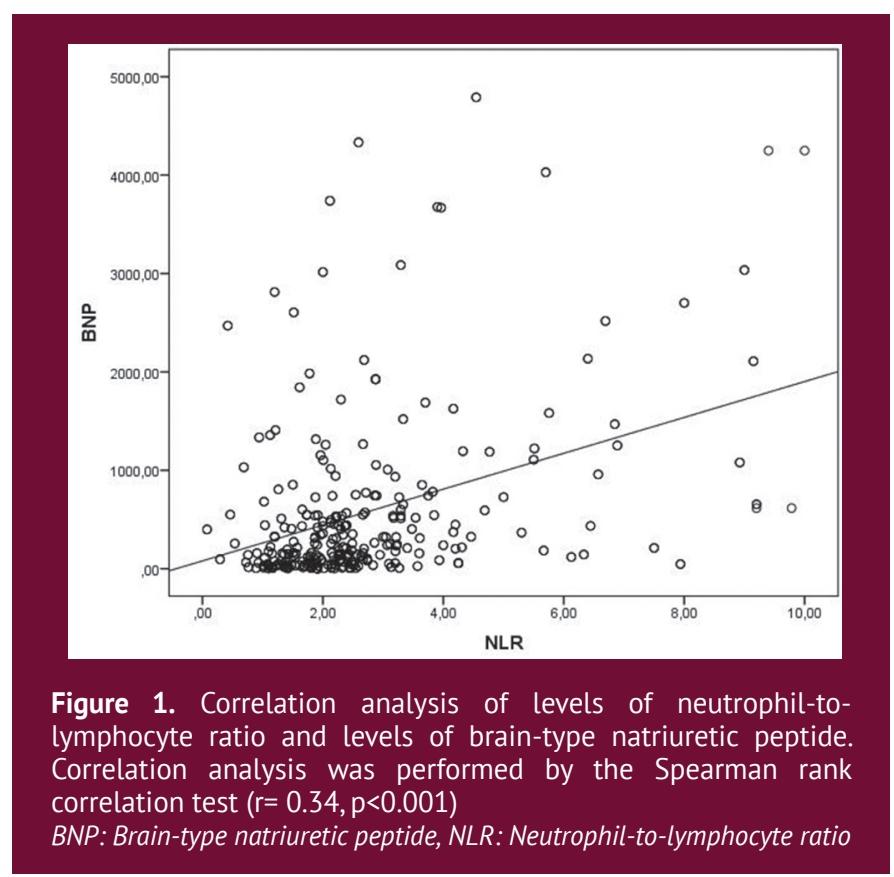


Table 1. Baseline characteristics of patients classified by neutrophil-to- lymphocyte ratio

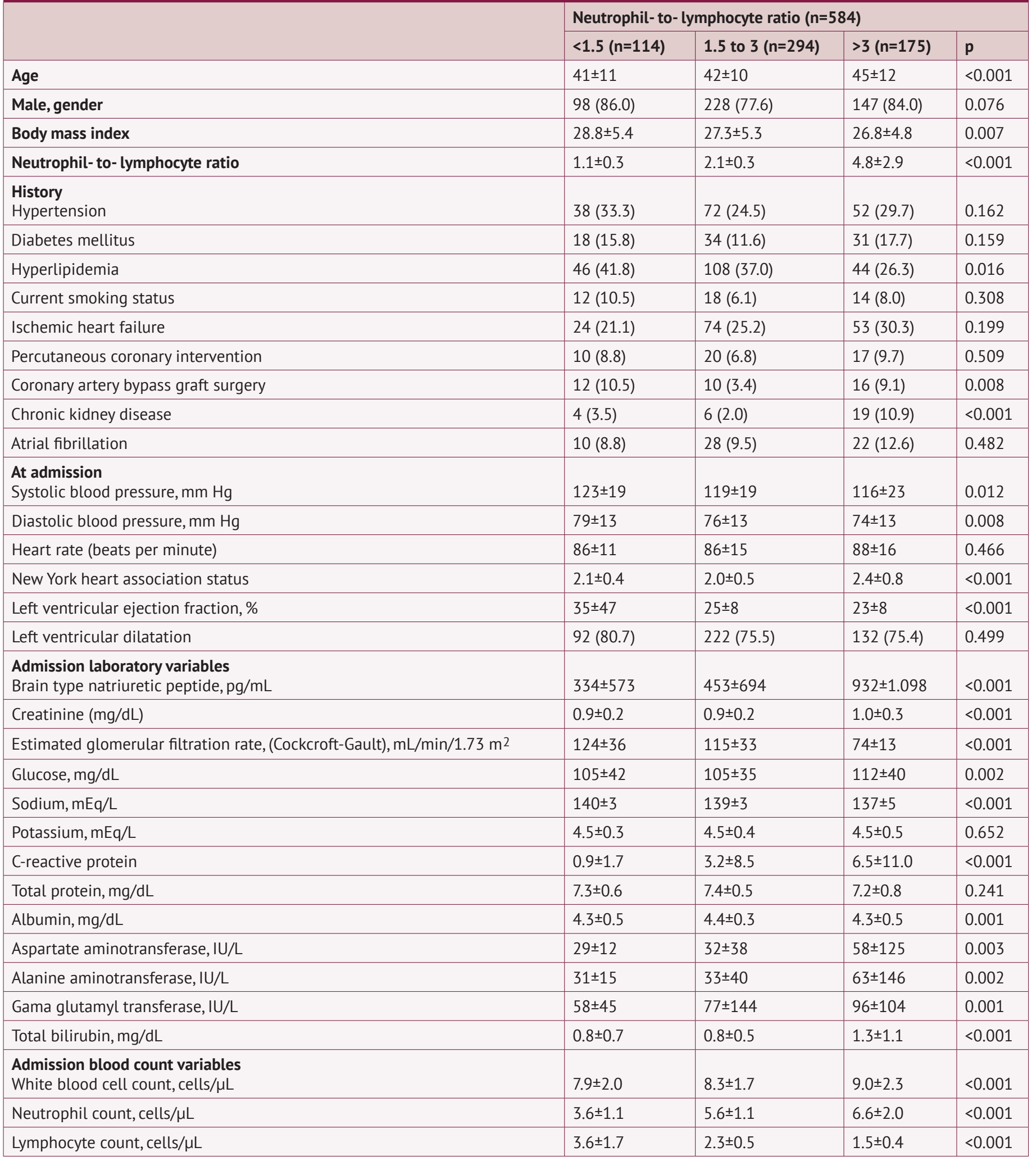




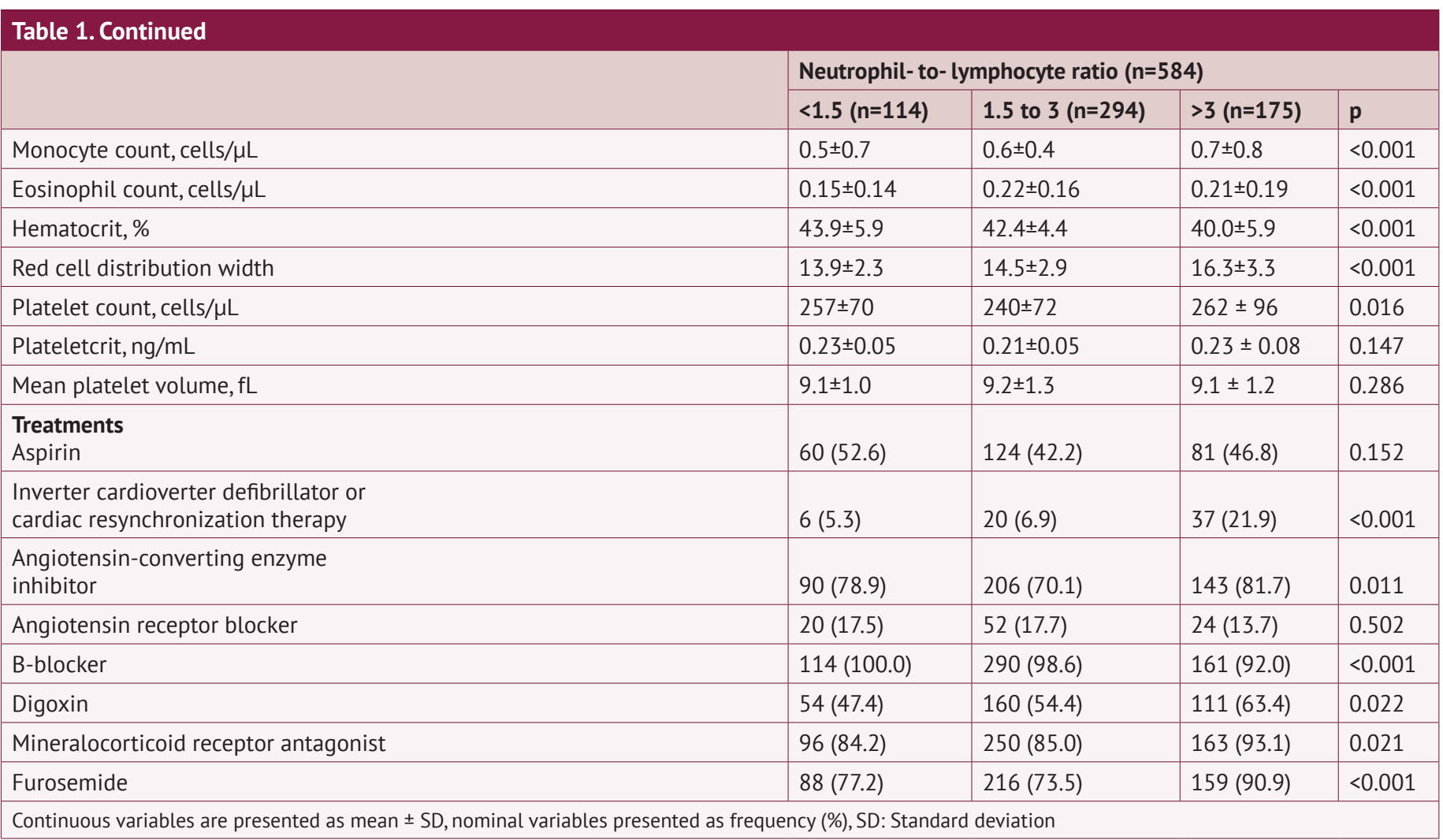

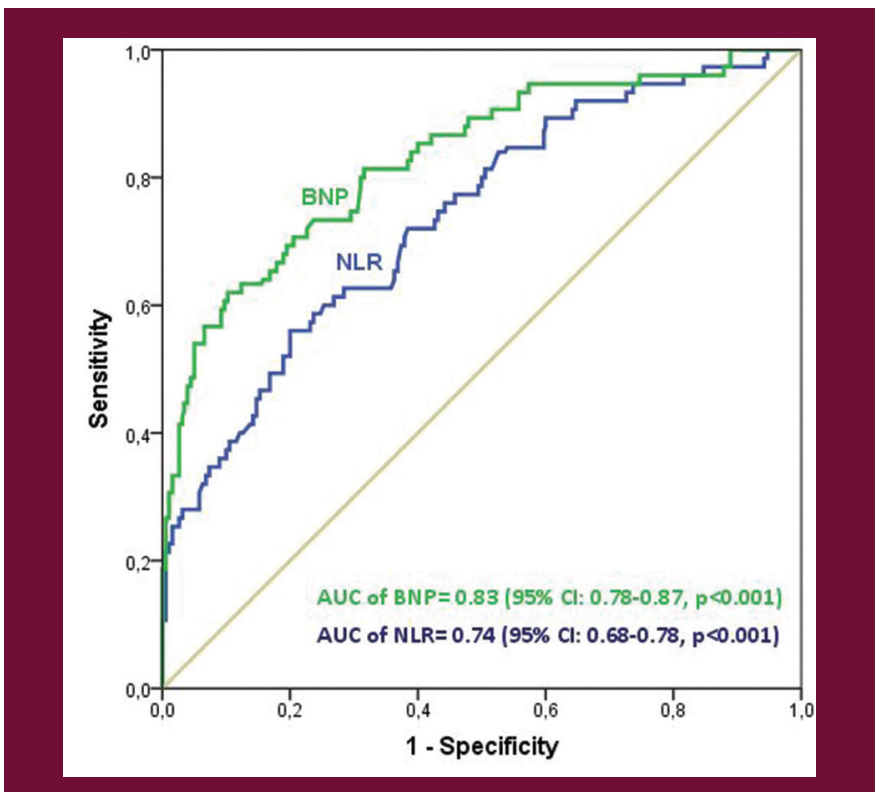

Figure 2. ROC analysis revealed that the best cut-off value of the BNP to predict the mortality was $445 \mathrm{pg} / \mathrm{mL}$ with $71 \%$ sensitivity and $80 \%$ specificity (AUC: $0.83 ; 95 \% \mathrm{Cl}: 0.78-0.87, \mathrm{p}<0.001$ ), and the best cut-off value of the NLR to predict the mortality was 2.3 with $71 \%$ sensitivity and $63 \%$ specificity (AUC: $0.74 ; 95 \% \mathrm{Cl}$ : $0.68-0.78, p<0.001)$

ROC: Receiver operating characteristic, AUC: Area under the curve, Cl: Confidence interval, BNP: Brain-type natriuretic peptide, NLR: Neutrophilto-lymphocyte ratio

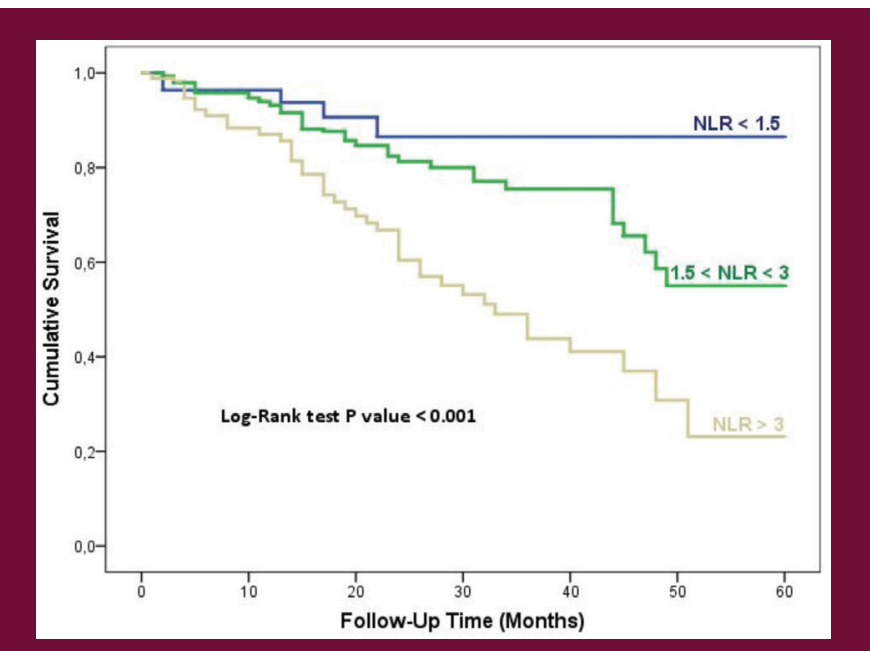

Figure 3. Kaplan-Meier curve for overall survival in patients with heart failure $(n=584)$ stratified by neutrophil-to-lymphocyte ratio NLR: Neutrophil-to-lymphocyte ratio 
in patients with HF and the high NLR was strongly correlated with the BNP.

Despite the fact that many advances have been made in $\mathrm{HF}$ by the respect of diagnosis and treatment, it still carries a high morbidity and mortality. There are many studies of NLR that have been performed recently in all departments of medical sciences. NLR has been studied in cardiac diseases including acute coronary syndromes, infective endocarditis, and diastolic and systolic heart failure $(6,11,12,13)$. Previous studies suggested significant predictive and prognostic value of NLR. Independently, either neutrophilia or lymphopenia has been related to increased morbidity and mortality in heart failure $(14,15)$. The usefulness of NLR in patients with acute heart failure has been reported in an extensive review, Uthamalingam et al. (16) revealed a 26-month follow-up study of 1.212 patients with acute decompensated heart failure (16). This study presented that patients with high NLR had significantly higher in-hospital and long-term mortality. In another study, Benites-Zapara et al. (4) confirmed this finding. In their study; they examined the patients with advanced heart failure and revealed that patients with

Table 2. Cox-proportional analysis and 5-year mortality by neutrophil-to- lymphocyte ratio

\begin{tabular}{|l|l|l|l|}
\hline \multirow{4}{*}{} & \multicolumn{2}{|l|}{$\begin{array}{l}\text { Neutrophil to lymphocyte ratio } \\
\text { (n= 584) }\end{array}$} \\
\cline { 2 - 4 } & $\begin{array}{l}<1.5 \\
\text { (n=114) }\end{array}$ & $\begin{array}{l}1.5 \text { to 3 } \\
\text { (n=294) }\end{array}$ & $\begin{array}{l}>3 \\
\text { (n=175) }\end{array}$ \\
\hline $\begin{array}{l}\text { 5-year mortality } \\
\text { Number of deaths }\end{array}$ & 10 & 66 & 81 \\
\hline Mortality, \% & 8.8 & 22.4 & 46.3 \\
\hline $\begin{array}{l}\text { Mortality, HR (95\% CI) } \\
\text { Model 1: unadjusted }\end{array}$ & $\begin{array}{l}\text { (reference) } \\
\text { (red }\end{array}$ & $\begin{array}{l}1.90 \\
(0.97-3.67)\end{array}$ & $\begin{array}{l}4.55 \\
(2.35-8.78)\end{array}$ \\
\hline $\begin{array}{l}\text { Model 2: adjusted for age } \\
\text { and gender }\end{array}$ & $\begin{array}{l}1.93 \\
\text { (reference) }\end{array}$ & $\begin{array}{l}1.9 .98-3.78) \\
\text { (2.68 }\end{array}$ & $(2.41-9.11)$ \\
\hline $\begin{array}{l}\text { Model 3: adjusted for } \\
\text { comorbidities and GFR }\end{array}$ & $\begin{array}{l}1 \\
\text { (reference) }\end{array}$ & $\begin{array}{l}1.91 \\
(0.92-3.79)\end{array}$ & $\begin{array}{l}4.04 \\
(2.53-6.02)\end{array}$ \\
\hline $\begin{array}{l}\text { Model 4: adjusted for } \\
\text { treatment }\end{array}$ & $\begin{array}{l}1 \\
\text { (reference) }\end{array}$ & $\begin{array}{l}1.96 \\
(0.95-3.63)\end{array}$ & $\begin{array}{l}4.97 \\
(3.03-7.75)\end{array}$ \\
\hline $\begin{array}{l}\text { Model 5: adjusted for all } \\
\text { covariablesb }\end{array}$ & $\begin{array}{l}1 \\
\text { (reference) }\end{array}$ & $\begin{array}{l}1.98 \\
(0.98-3.42)\end{array}$ & $\begin{array}{l}4.22 \\
(2.66-5.86)\end{array}$ \\
\hline
\end{tabular}

Abbreviations: GFR, glomerular filtration rate, HR, hazard ratio, b: Includes demographics (age, gender); first measurement of the following laboratory values (creatinine, brain type natriuretic peptide, admission glomerular filtration rate calculated by Cockcroft Gault, glucose, sodium, potassium, C-reactive protein, total protein, albumin, aspartate aminotransferase, alanine aminotransferase, gama-glutamyl transferase, total bilirubin, white blood cell count, neutrophil count, lymphocyte count, monocyte count, eosinophil count, hematocrit, red cell distribution width, platelet count, mean platelet volume, plateletcrit); comorbidities (diabetes, hypertension, hyperlipidemia, cerebrovascular disease, chronic obstructive pulmonary disease, atrial fibrillation, left ventricular dilatation) and treatments. $\mathrm{Cl}$ : Confidence interval, HR: Hazard ratio, GFR: Glomerular filtration rate high NLR had higher cardiac transplantation and mortality rates. Additionally, Durmus et al. (5) showed a significant relationship between increasing NLR and decreasing LVEF. All these studies suggest that inflammatory mechanisms have an important role in heart failure. Although these studies introduced a significant inverse correlation between NLR and heart failure, the patients with stable heart failure without acute decompensation were not examined in Uthamalingam et al.'s (16) study. Acute decompensating heart failure has a substational role in NLR, and these patients are more prone to death. Furthermore, Benites-Zapata et al. (4) included only the patients with advanced heart failure. Therefore, the patients with lower NYHA status were not evaluated in their study. The current study included all the consecutive patients with heart failure who were not in acute decompensating state according to the "ESC guidelines for the diagnosis and treatment of acute and chronic heart failure 2012". Albeit the study population was different from the previous studies on heart failure, the results were similar. The long-term mortality had the highest rates at NLR level of $>3$ and that had 4.5 -times higher mortality rates than NLR level of $<1.5$.

Another important issue in $\mathrm{HF}$ is diagnostic difficulty. Because the signs and symptoms of HF are non-specific, many patients with suspected HF referred for echocardiography are not found to have an important cardiac abnormality. Because of unavailability of echocardiography, an alternative approach to diagnosis is to measure the $\operatorname{BNP}(3,17,18)$. Commonly, a normal BNP level excludes significant cardiac disease. Despite the fact that BNP has a substantial role in the diagnosis of HF, it is still commonly not available in many hospitals especially in developing countries. This difficulty attenuates the diagnostic value of the natriuretic peptides. In the current study, NLR level showed a very strong correlation with the BNP $(r=0.340, p<0.001)$. Furthermore, a cut off NLR value of 2.3 has $71 \%$ sensitivity and $63 \%$ specificity in predicting five-year long-term mortality. These findings suggest that NLR may become a simple and cheap biomarker in the diagnosis and prognosis of heart failure. Because the blood count is usually ordered in patients with $\mathrm{HF}$, the ability to classify a HF population without additional testing is important.

\section{Study Limitations}

The current study has several limitations. Firstly, this was a single center, retrospective and observational study. Secondly, the patients who underwent cardiac transplantation were not included. Thirdly, only baseline measures of NLR were evaluated. NLR values overtime and their effect on clinical outcomes were not obtained. Fourthly, due to the problems with insurance policies and hospital protocols, some of the patients had not inverter cardioverter defibrillator even if they were suitable. 
Fifthly, although we used multivariable analysis, we could not exclude the possibility of residual unmeasured covariables which might influence the outcomes.

\section{Conclusion}

NLR is a non-invasive, widely available and cheap parameter for predicting long-term outcome in patients with HF. The current study results showed that patients with a high NLR had higher long-term mortality. Furthermore, because of significant correlation with BNP, NLR may be used as a diagnostic test for HF.

\section{Ethics}

Ethics Committee Approval: This study was approved by the institutional ethical and scientific committee.

Informed Consent: Consent was obtained from all patients or their relatives in our study.

Peer-review: Externally and internally peer-reviewed.

\section{Authorship Contributions}

Surgical and Medical Practices: Ü.K., N.G.,K.K., Concept:Ü.K., N.G., K.K., Design: Ü.K., N.G., K.K., Data Collection or Processing: Ü.K., N.G., K.K., Analysis or Interpretation: Ü.K., N.G., K.K., Literature Search: Ü.K., N.G., K.K., Writing: Ü.K., N.G., K.K.

Conflict of Interest: No conflict of interest was declared by the authors.

Financial Disclosure: The authors declared that this study received no financial support.

\section{References}

1. Ross R. Atherosclerosis -- an inflammatory disease. N Engl J Med. 1999;340:115-126. [Crossref]

2. Libby P. What have we learned about the biology of atherosclerosis? The role of inflammation. Am J Cardiol. 2001;88:3J-6J. [Crossref]

3. Ponikowski P, Voors AA, Anker SD, Bueno H, Cleland JGF, Coats AJS, et al. 2016 ESC Guidelines for the diagnosis and treatment of acute and chronic heart failure: The Task Force for the diagnosis and treatment of acute and chronic heart failure of the European Society of Cardiology (ESC). Developed with the special contribution of the Heart Failure Association (HFA) of the ESC. Eur Heart J. 2016;37:2129-2200. [Crossref]

4. Benites-Zapata VA, Hernandez AV, Nagarajan V, Cauthen CA, Starling RC, Tang WHW. Usefulness of neutrophil-to-lymphocyte ratio in risk stratification of patients with advanced heart failure. Am J Cardiol. 2015;115:57-61. [Epub 2014 Oct 13] [Crossref]
5. Durmus E, Kivrak T, Gerin F, Sunbul M, Sari I, Erdogan O. Neutrophil-toLymphocyte Ratio and Platelet-to-Lymphocyte Ratio are Predictors of Heart Failure. Arq Bras Cardiol. 2015;105:606-613. [Crossref]

6. Ghaffari S, Nadiri M, Pourafkari L, Sepehrvand N, Movasagpoor A, Rahmatvand N, et al. The predictive Value of Total Neutrophil Count and Neutrophil/Lymphocyte Ratio in Predicting In-hospital Mortality and Complications after STEMI. J Cardiovasc Thorac Res. 2014;6:35-41. [Crossref]

7. Schiller NB, Shah PM, Crawford M, DeMaria A, Devereux R, Feigenbaum $\mathrm{H}$, et al. Recommendations for quantitation of the left ventricle by two dimensional echocardiography: American Society of Echocardiography Committee on Standards, Subcommittee on Quantitation of TwoDimensional Echocardiograms. J Am Soc Echocardiogr. 1989;2:358-367. [Crossref]

8. Cockcroft DW, Gault MH. Prediction of creatinine clearance from serum creatinine. Nephron. 1976;16:31-41. [Crossref]

9. Mehta RL, Kellum JA, Shah SV, Molitoris BA, Ronco C, Warnock DG, et al. Acute Kidney Injury Network. Acute Kidney Injury Network: report of an initiative to improve outcomes in acute kidney injury. Crit Care. 2007;11:R31. [Crossref]

10. Amin AP,Salisbury AC,McCullough PA, Gosch K,Spertus JA, Venkitachalam L, et al. Trends in the incidence of acute kidney injury in patients hospitalized with acute myocardial infarction. Arch Intern Med. 2012;172:246-253. [Crossref]

11. Bozbay M, Ugur M, Uyarel H, Cicek G, Koroglu B, Tusun E, et al. Neutrophilto-lymphocyte ratio as a prognostic marker in infective endocarditis: inhospital and long-term clinical results. J Heart Valve Dis. 2014;23:617623. [Pubmed]

12. Karagöz A, Vural A, Günaydın ZY, Bektaş O, Gül M, Çelik A, et al. The role of neutrophil to lymphocyte ratio as a predictor of diastolic dysfunction in hypertensive patients. Eur Rev Med Pharmacol Sci. 2015;19:433-440. [Pubmed]

13. Avci A, Alizade E, Fidan S, Yesin M, Guler Y, Kargin R, et al. Neutrophil/ lymphocyte ratio is related to the severity of idiopathic dilated cardiomyopathy. Scand Cardiovasc J. 2014;48:202-208. [Crossref]

14. Acanfora D, Gheorghiade M, Trojano L, Furgi G, Pasini E, Picone C, et al. Relative lymphocyte count: a prognostic indicator of mortality in elderly patients with congestive heart failure. Am Heart J. 2001;142:167-173. [Crossref]

15. Huehnergarth KV, Mozaffarian D, Sullivan MD, Crane BA, Wilkinson CW, Lawler RL, et al. Usefulness of relative lymphocyte count as an independent predictor of death/urgent transplant in heart failure. Am J Cardiol. 2005;95:1492-1495. [Crossref]

16. Uthamalingam S, Patvardhan EA, Subramanian S, Ahmed W, Martin W, Daley $\mathrm{M}$, et al. Utility of the neutrophil to lymphocyte ratio in predicting long-term outcomes in acute decompensated heart failure. Am J Cardiol. 2011;107:433-438. [Crossref]

17. Ewald B, Ewald D,Thakkinstian A,Attia J. Meta-analysis of B type natriuretic peptide and $\mathrm{N}$-terminal pro $\mathrm{B}$ natriuretic peptide in the diagnosis of clinical heart failure and population screening for left ventricular systolic dysfunction. Intern Med J. 2008;38:101-113. [Crossref]

18. Doust JA, Glasziou PP, Pietrzak E, Dobson AJ. A systematic review of the diagnostic accuracy of natriuretic peptides for heart failure. Arch Intern Med. 2004;164:1978-1984. [Crossref] 